\title{
Synthesis and characterization of $\mathrm{Pt}$ on novel catalyst supports for the $\mathrm{H}_{2}$ production in
} the Westinghouse cycle

Justo Lobato, Sergio Díaz-Abad, Mª Carmen Peláez, María Millán and Manuel A. Rodrigo

Chemical Engineering Department. Enrique Costa Building. University of Castilla-La Mancha. Av. Camilo Jose Cela n 12. Ciudad Real (13071). Spain.

\begin{abstract}
This work shows the preparation and physicochemical and electrochemical characterization of Pt based catalysts supported on two different catalyst supports (Vulcan carbon and $\mathrm{SiC} / \mathrm{TiC}$ ) with a $40 \mathrm{wt} \% \mathrm{Pt}$ content for the depolarised $\mathrm{SO}_{2}$ electro-oxidation in the hybrid sulfur process, which is a promising approach for the hydrogen production. The Pt based catalysts supported on carbon showed the lowest Pt crystallite size, but the electrochemical surface area of the Pt deposited on the $\mathrm{Si}_{0.9} \mathrm{CTi}_{0.1} \mathrm{C}$ was the highest of the three catalysts prepared in the lab under the same operation conditions. The Pt catalysts supported on the novel $\mathrm{SiC} / \mathrm{TiC}$ based material are promising catalysts for this technology as they showed high catalyst activity and durability in sulfuric acid conditions.
\end{abstract}

Keywords: Catalyst support; Durability; $\mathrm{SiC} / \mathrm{TiC} ; \mathrm{SO}_{2}$ electro-oxidation; Westinghouse cycle

\section{Introduction}

Energy demand is constantly growing, which causes an over-consumption of fossil fuels for satisfying this demand, which increases the release of pollutants to the atmosphere [1]. As a consequence, governments and the scientific community are pursuing the utilization and development of clean and renewable sources of energy production [2]. The share in energy production of renewable energies such as solar or eolic has importantly grown over the last decade. Nevertheless, their reliability is highly dependent on the weather and, sometimes, it is 
difficult to predict them [3]. This disadvantage, together with their intermittence makes it necessary to develop technologies to storage the electricity produced from those energies [4]. Considering that the idea is to use renewable energies, the way to storage them has to be also renewable. To do so, Hydrogen is known as the ideal energy carrier and processes for its production are becoming a widely studied field. For clean or "green" hydrogen production [5,6], the ideal raw material is, obviously, water. This molecule can be split into oxygen and the desired hydrogen. Among all the different water splitting processes [7-11], the Westinghouse process in which $\mathrm{SO}_{2}$ and water are electro-oxidised, is one of certain interest [9]. The justification for this interest is that when energetically compared against direct water electrolysis, the energy consumption is much lower for the sulfur cycle [12]. A theoretical cell potential of $1.23 \mathrm{~V} @ 25^{\circ} \mathrm{C}$ (vs SHE) is needed for direct water electrolysis, meanwhile, only a cell potential of $0.16 @ 25^{\circ} \mathrm{C}$ (vs SHE) is required for the mentioned depolarized $\mathrm{SO}_{2}$ water electrolysis process. The Westinghouse process is also known as the Hybrid Sulfur cycle (HyS) because it combines an electrochemical step (which is to be powered with solar or eolic energy) in which hydrogen and $\mathrm{H}_{2} \mathrm{SO}_{4}$ (equations 1 and 2) are produced, and a thermochemical step in which sulfuric acid is decomposed [13] into oxygen and $\mathrm{SO}_{2}$ which is recirculated to the electrolyser [14].

$$
\begin{aligned}
& \mathrm{SO}_{2}(\mathrm{aq})+2 \mathrm{H}_{2} \mathrm{O} \rightarrow \mathrm{H}_{2} \mathrm{SO}_{4}(\mathrm{aq})+2 \mathrm{H}^{+}+2 \mathrm{e}^{-} \\
& 2 \mathrm{H}^{+}+2 \mathrm{e}^{-} \quad \rightarrow \mathrm{H}_{2}(\mathrm{~g})
\end{aligned}
$$

For this process to be economically feasible, there is an operating target for the electrolysis step of $0.5 \mathrm{~A} / \mathrm{cm}^{2}$ at $0.6 \mathrm{~V}$ [15]. As the potentials for the HyS cycle are substantially lower than for the simpler direct water electrolysis, the thermal energy needed for the thermal decomposition of the produced sulfuric acid has to be lower than the thermal equivalence in cell potentials.

Big efforts are being made on the development of novel materials for improving the electrochemical step [16]. Current operating temperatures for this process are in the range of 80$100^{\circ} \mathrm{C}$ due to restrictions of the Nafion membrane which is the most common used polymer for 
this application [17]. A higher operating temperature in the electrolysis step would enhance reaction kinetics and also the temperature of the produced sulfuric acid would be higher so less thermal energy would be needed for the concentration and decomposition step [18]. Thus, new materials for the proton exchange membrane are being tested, among them PBI based membranes are a promising alternative [19-21]. As catalyst, a broad range of catalysts has been studied for the anode compartment, which is the most problematic, being platinum supported on carbon the one which has shown the most promising results. An interesting review of this topic can be found elsewhere [22].

The cost of the catalyst is by far the largest portion, so aiming a reduction in electrolyzer costs, supported catalysts for the $\mathrm{SO}_{2}$ depolarized electrolysis are being developed to reduce the amount of noble metal employed. Catalyst with durability at high temperatures have to be also studied, as corrosion at that temperatures is higher than for the normal operation temperature for this application [23]. The most common support for platinum for the, $\mathrm{SO}_{2}$ depolarized electrolysis, is Vulcan carbon due to its low cost [24]. However, corrosion of carbon supports has been identified as the major contributor to catalyst failure [25] for PEM fuel cells, in particular, for platinum-based catalysts [26]. The catalyst development is focused on the reduction of the Pt amount and the investigation of new supports to avoid fast degradation and increasing catalyst lifetime. In the attempt to increase catalyst efficiency and durability, different supports have been studied, searching for higher chemical and physical durability and higher surface area in order to increase catalyst utilization [27]. Therefore, noncarbon support materials are at the focus of researchers. Some of these advanced materials which have shown to be promising alternatives to carbon supports are metals which act as catalyst supports [28-30], metal oxides [31], nitrides [32], borides [33] or carbides [34-36]. Among all of them, SiC and TiC form the carbide family have shown promising results for PEM fuel cells showing better stability than Vulcan carbon $[27,36,37]$. In this work, as result of the promising results reached in our group, $\mathrm{Pt}$ supported on $\mathrm{SiC} / \mathrm{TiC}$ (with two different $\mathrm{SiC} / \mathrm{TiC}$ ratios) catalysts were synthesized and physicochemical and electrochemically characterized. They were also tested for 
the $\mathrm{SO}_{2}$ water electrolysis for the first time. For comparison purposes, Pt/Vulcan carbon catalyst was also prepared using the same procedure and tested for the $\mathrm{SO}_{2}$ water electrolysis.

\section{Experimental}

\subsection{Catalysts synthesis}

Different catalysts were prepared by the impregnation method using $\mathrm{NaBH}_{4}$ as reducing agent [38], using the different $\mathrm{SiC} / \mathrm{TiC}$ samples as catalyst support and the Vulcan carbon for comparison purposes. The process consists on preparing $500 \mathrm{mg}$ of each different catalyst with the target of $40 \mathrm{wt} \%$ platinum deposited on each support. Chloroplatinic acid hexahydrate (Sigma Aldrich) was used as precursor salt because of its good solubility. Synthesis was carried out in $500 \mathrm{~mL}$ of $0.1 \mathrm{M}$ formic acid solution at $80{ }^{\circ} \mathrm{C}$ with stirring. Support was added during the heating phase to ensure a homogeneous mix and to obtain a better platinum dispersion on the support. When the temperature reached $80{ }^{\circ} \mathrm{C}$, the precursor salt dissolved in deionized water was slowly added drop by drop during 15 min approx. in order to improve platinum dispersion in the media. The reaction was conducted with stirring and heating for one hour more. After that, solution was filtered, and the solid was dried in a furnace for $6 \mathrm{~h}$ at least, in order to remove the solvent. Dry catalysts obtained were weighted and characterized.

SiC/TiC powders with different TiC molar content 10 and $20 \%$ were commercially provided by SICAT Company (Paris, France).

\subsection{Physicochemical characterization}

Real platinum content was determined by inductively couple plasma optical emission spectrometry (ICP-OES) using a Varian Liberty RL spectrometer. Solid samples, $0.01 \mathrm{mg}$, were subjected to acid digestion process using $3 \mathrm{~mL}$ of $\mathrm{HF}, 2 \mathrm{~mL}$ of $\mathrm{HCl}$ and $2 \mathrm{~mL}$ of $\mathrm{H}_{2} \mathrm{O}_{2}$ (all reagents from PanReac used as received), in order to dissolve the metals contained in the sample. 
Platinum dispersion of the catalysts was analysed by TEM micrographs, using a Jeol 2100, working at $200 \mathrm{kV}$, with a double-twist sample holder, $\left( \pm 30^{\circ}\right)$ and EDS (Oxford Link). Samples were dispersed in acetone media, and a drop of sample was deposited on a copper rack, covered with perforated C (holey carbon, EMS). XRD analysis were performed by means of a Philips PW-1700 diffractometer equipped with $\mathrm{Cu} \mathrm{K} \alpha$ radiation. The $2 \theta$ angular regions between 5 and $90^{\circ}$ were explored at a scan rate of $0.1^{\circ} \mathrm{s}^{-1}$. The Scherrer equation was used to calculate the platinum crystallite size:

$$
\mathrm{L}_{\mathrm{C}}=\frac{0,89 \cdot \lambda}{\mathrm{B} \cdot \cos (\theta)}
$$

Where $L c$ is the crystal size in $\mathrm{nm}, \lambda$ corresponds to the $K \alpha$ radiation of copper $(\lambda=0.15418$ $\mathrm{nm}), B$ is a parameter related to the full width at half maximum intensity of the peak, and $\theta$ is the angle corresponding to $\mathrm{I}_{\max }(\mathrm{rad})$.

\subsection{Electrochemical characterization}

Once the catalysts were prepared, catalyst inks using N,N dimethylacetamide (DMAc) as solvent and PBI as ionomer were prepared and deposited onto commercial electrodes (Freudenberg Vliesstoffe, H23C2) to get a Pt loading of $0.5 \mathrm{mg} / \mathrm{cm}^{2}$. The electrochemical measurements were carried out on an Autolab potentiostat/galvanostat (PGSTAT-204). Pt wire and $\mathrm{Ag} / \mathrm{AgCl}$ electrodes were used as the counter and reference electrode, respectively. The working electrode was the electrode prepared in our lab using the different catalyst tested in this work. 


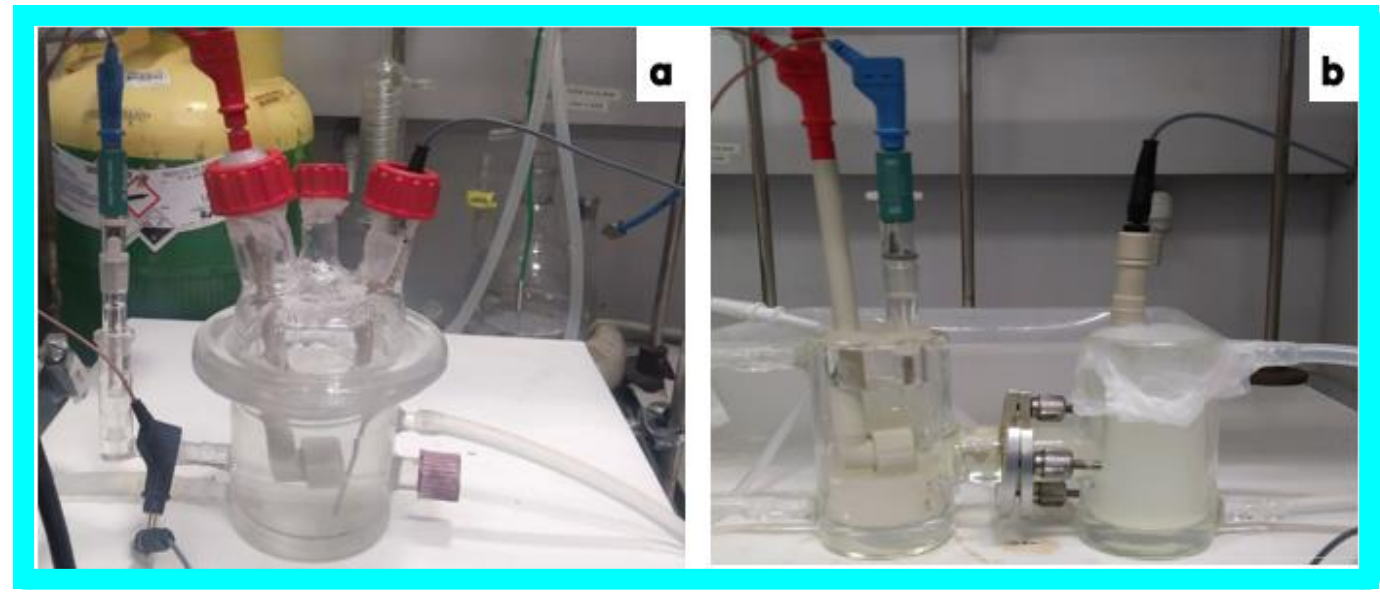

Figure 1. Electrochemical set-ut for the electrochemical characterization of the different catalysts

CV voltammetries were carried out in a half-cell (Fig. 1a), to evaluate the electrochemical surface active area (ECSA), calculated through the $\mathrm{H}_{2}$ absorption/desorption peaks, using the Eq. (4) [39]:

$$
\mathrm{ECSA}=\frac{\mathrm{A}_{(\mathrm{Pt})}}{\mathrm{v} \times \mathrm{C}} \times \frac{1}{\mathrm{~L}}
$$

Where ECSA is the Electrochemical Surface Area $\left(\mathrm{m}^{2} \mathrm{gPt}^{-1}\right), \mathrm{A}_{(\mathrm{Pt})}$ is the surface under the hydrogen desorption peak $\left(\mathrm{AV} \mathrm{cm}{ }^{-2}\right), \mathrm{v}$ is the scan rate $\left(\mathrm{V} \mathrm{s}^{-1}\right), \mathrm{C}$ is a constant related to the required load to reduce the proton layer on the active platinum $\left(0.21 \mathrm{mC} \mathrm{cm}^{-2}\right)$ and $\mathrm{L}$ is the Platinum content in the catalyst layer (in our case, it was $0.5 \mathrm{mgPt} \mathrm{cm}{ }^{-2}$ ).

In order to evaluate the stability and duratbility of the different catalysts, chronoamperometry tests were performed. chronoamperometry tests were performed in a h-cell (Fig 1 b). $\mathrm{SO}_{2}$ was bubbled for one minute. The initial and final concentration of $\mathrm{SO}_{2}$ was measured by the titration method considering the following reaction and using Iodine.

$$
\mathrm{SO}_{2}+\mathrm{I}_{2}+2 \mathrm{H}_{2} \mathrm{O} \rightarrow \mathrm{H}_{2} \mathrm{SO}_{4}+2 \mathrm{HI}
$$




\section{Results and Discussion}

\subsection{Physicochemical analysis}

Firstly, it should be highlighted that the binary carbide $\mathrm{SiC} / \mathrm{TiC}$ is not a physical mixture of both carbides, but a compound obtained from Si and Ti source [36].

In Table 1 the Pt content on the different supports and the commercial one, for comparison purposes, is shown. For comparison purposes, as the synthesis method employed to prepare the catalysts is not optimized and automatized as the commercial one. It was necessary to determine the platinum percentage in each catalyst, as the catalytic activity depends on the amount of noble metal deposited on the support. Also, the particle size plays an important role in the catalytic activity, as the ECSA depends partially on it [27,41].Actual Pt content in all the cases is very similar to the nominal one $(40 \%)$. So, the procedure used to synthesize the catalyst allowed us to platinize the support with the desired Pt content. The successful deposition of metallic platinum on the different supports is confirmed by the X-ray difractograms shown in Figure 2. The Pt(111), Pt(200) Pt (220), and Pt(311) planes can be clearly seen, which correspond to the $41.0^{\circ}, 46.1^{\circ}, 67.4^{\circ}$, and $82.0^{\circ}$, respectively. These peaks correspond with the expected ace-centered cubic crystal structure for platinum. The main peaks associated to the binary carbide, $35.5^{\circ}$ for SIC and $41.7^{\circ}$ for the TiC are also noticeable [36]. The peak around $26^{\circ}$ is characteristic of the carbonaceous supports [42]. Moreover, no phase changes or formation of oxides were observed for any of the catalysts, indicating that the novel binary support remains stable during the platinum deposition process. As the peak observed for the $\operatorname{Pt}(111)$ (around $\left.41^{\circ}\right)$ is very close to the $\operatorname{SiC}(200)\left(41.6^{\circ}\right)$, the average platinum crystallite size was calculated from the $\operatorname{Pt}(200)$ plane by using the well-known Scherrer formula. $\operatorname{This} \operatorname{Pt}(200)$ is often used to evaluate the crystallite Pt-based catalysts [43,44]. The obtained platinum crystallite size values are shown in Table 1. Pt crystal size values are observed to be higher for the case of the catalyst that used the binary carbide as support than the one that used the Vulcan carbon as support. The lower BET surface area of the SiC/TiC with $20 \%$ of TiC, $\left(55.4 \mathrm{~m}^{2} \mathrm{~g}^{-1}\right)$ with respect to the one with $10 \%$ of $\mathrm{TiC}$ (around $100 \mathrm{~m}^{2} \mathrm{~g}^{-1}$ ) could explain the highest $\mathrm{Pt}$ 
crystallite size. Nevertheless, this value is similar to others values found in literature for the same support [36]. For the case of the catalyst on the support with $10 \%$ of $\mathrm{TiC}$, the obtained value $(5.45 \mathrm{~nm})$ is even lower than the obtained using the same support in a previous work of our group [36] and similar to others obtained by other authors but using $\mathrm{SiC}$ as catalyst support [45].

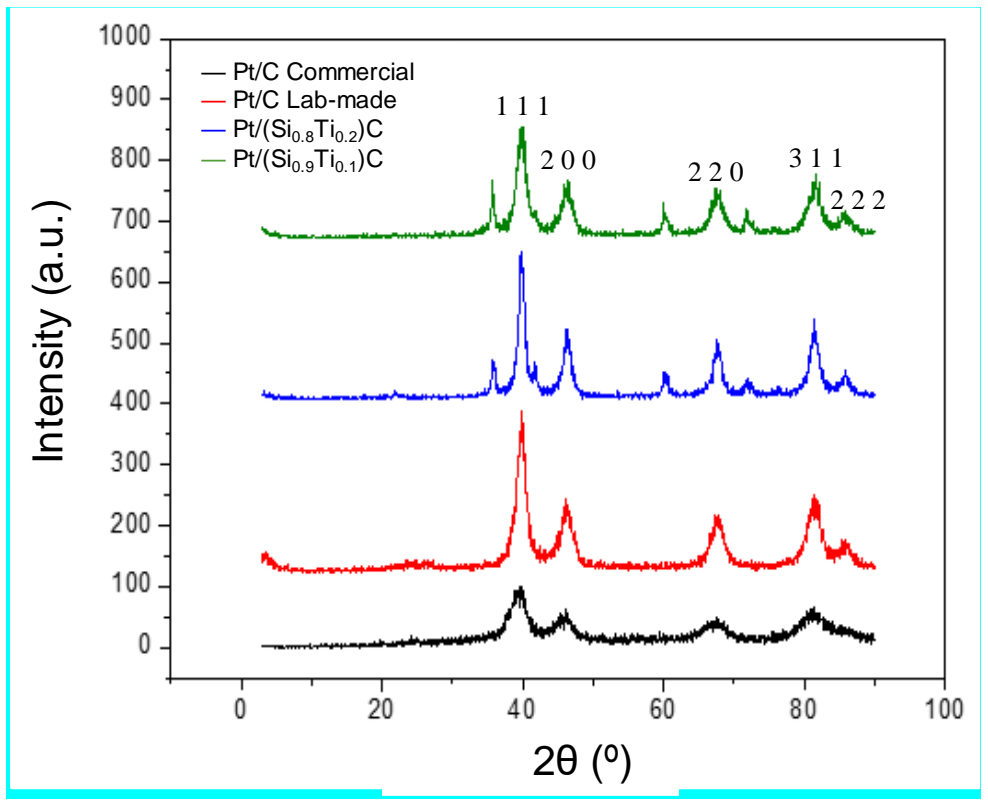

Figure 2. XDR patterns of the different prepared catalysts

Table 1. Platinum content and particle size for the commercial and the lab-made catalysts

\begin{tabular}{ccccc}
\hline Catalyst & Commercial Pt/C & Lab-made Pt/C & $\mathbf{P t} /\left(\mathbf{S i}_{\mathbf{0} .8} \mathbf{T i}_{\mathbf{0} .2}\right) \mathbf{C}$ & $\mathbf{P t} /\left(\mathbf{S i}_{\mathbf{0} . \mathbf{T}} \mathbf{T i}_{\mathbf{0} . \mathbf{1}}\right) \mathbf{C}$ \\
\hline$\% \mathbf{P t}$ & 40.28 & 39.47 & 38.90 & 42.74 \\
\hline Crystal size (nm) & 2.59 & 4.50 & 7.77 & 5.45 \\
\hline
\end{tabular}

When the Pt crystallite size of the commercial $(2.59 \mathrm{~nm})$ catalyst is compared with the one prepared in our lab $(4.50 \mathrm{~nm})$ and using also Vulcan carbon as support it can be seen clearly that 
its value is very low, almost the half that the one obtained in the lab. This means that not only the support but the catalyst synthesis procedure has influence on the Pt crystallite size.

In Figure 3 TEM micrographs of different catalyst samples studied in this work are depicted. Pt nanoparticles appear darker compared to SiC/TiC. In table 1, the particle size of the Pt particles is shown for each catalyst. As it was expected, according to the results obtained from the XRD analyses, the catalysts supported on Vulcan carbon showed the lowest Pt particle sizes and better distribution. This better distribution and lower particle size are explained due to the BET surface area of the supports, around $230 \mathrm{~m}^{2} \mathrm{~g}^{-1}$ for the commercial Vulcan [46,47] compared with the $99,5 \mathrm{~m}^{2} \mathrm{~g}^{-1}$ for $\left(\mathrm{Si}_{0.9} \mathrm{Ti}_{0.1}\right) \mathrm{C}$ and $55,4 \mathrm{~m}^{2} / \mathrm{g}^{-1}$ for $\left(\mathrm{Si}_{0.8} \mathrm{Ti}_{0.2}\right) \mathrm{C}$, where the catalyst agglomeration is noticeable. Thus, a good particle distribution prevents catalyst agglomeration and a smaller catalyst particle size is obtained [27]. This agglomeration effect has also been observed by Dihman et al., when they prepared Pt catalyst with a $20 \%$ wt on $\mathrm{SiC}$ supports whose BET surface area was around $20 \mathrm{~m}^{2} \mathrm{~g}^{-1}[45]$. 

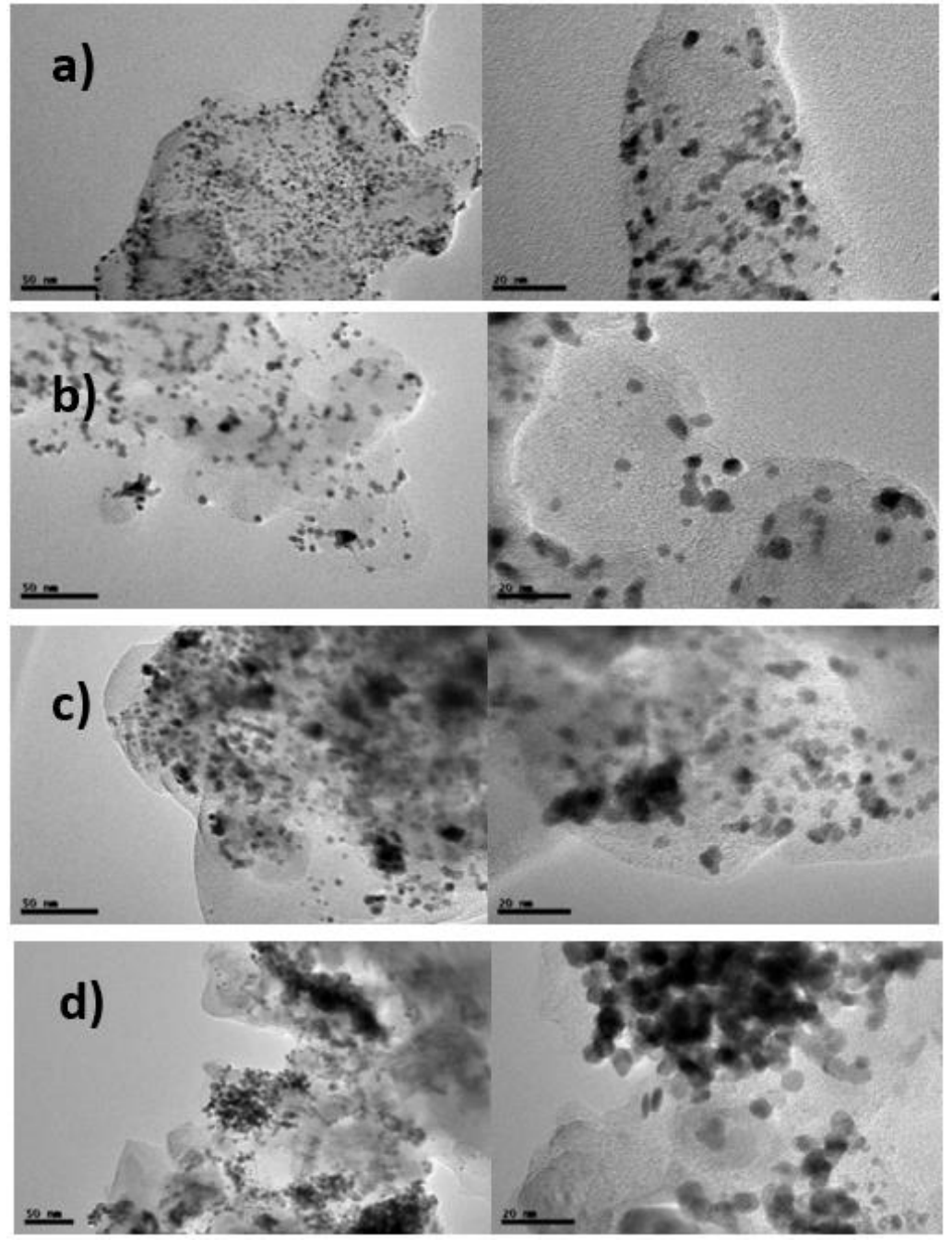

Figure 3. TEM images of the different catalysts. a) Commercial Pt/C, b) Lab-Made Pt/C, c) $\mathrm{Pt} /\left(\mathrm{Si}_{0.9} \mathrm{Ti}_{0.1}\right) \mathrm{C}$ and d) $\mathrm{Pt} /\left(\mathrm{Si}_{0.8} \mathrm{Ti}_{0.2}\right) \mathrm{C}$

The electrochemical surface area (ECSA) was obtained by cyclic voltammetry in $\mathrm{H}_{2} \mathrm{SO}_{4} 1 \mathrm{M}$ in a half-cell previously bubbled with nitrogen for 20 minutes. For this measurement, 50 cycles were carried out within a potential range of -0.2 and $1.0 \mathrm{~V}(\mathrm{vs} \mathrm{Ag} / \mathrm{AgCl})$ with a scan rate of $0.05 \mathrm{~V} / \mathrm{s}[36,48]$.

Figure 4 shows the obtained voltammograms for each studied catalyst at cycle 50th from which the ECSA was calculated. 


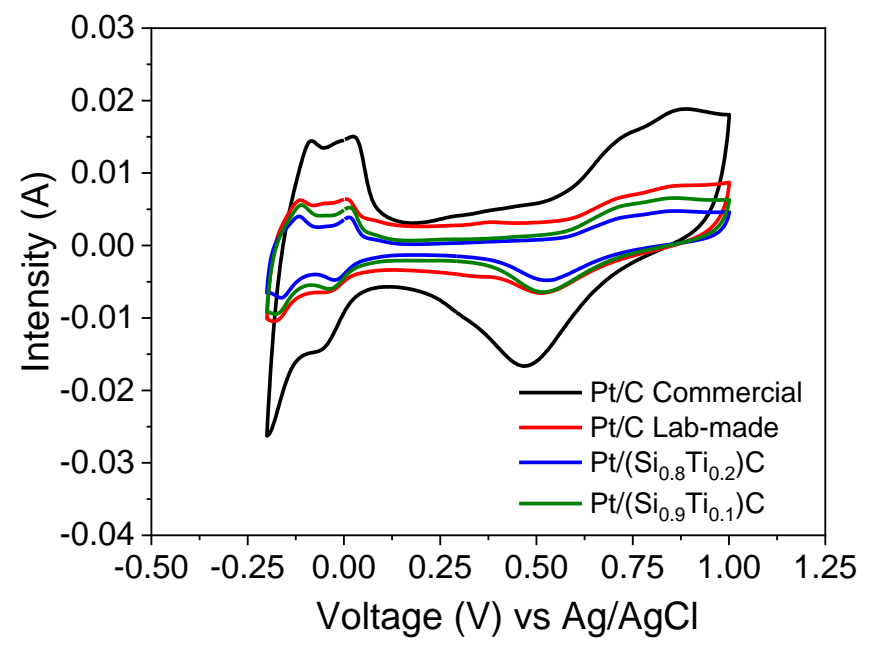

Figure 4. Cyclic voltammograms for the different catalysts. Conditions: $20^{\circ} \mathrm{C}, 1 \mathrm{M} \mathrm{H}_{2} \mathrm{SO}_{4}$ (inertized with $\mathrm{N}_{2}$ ), $50 \mathrm{mV} \mathrm{s}-1$ vs RHE. Cycle 50

As observed in Table 2, the ECSA for the commercial platinum catalyst is much larger than for the rest of the lab-made catalysts, which show similar values among them. These results may be justified based on the crystallite size of the platinum particles shown in table 1 . The considerably lower particle size of the commercial catalyst and better distribution lead to higher ECSA. Also, platinum crystal agglomeration observed in the TEM pictures in Figure 3 is more evident for the catalysts supported on $\mathrm{SiC} / \mathrm{TiC}$ due to their lower surface area.

Table 2 ECSA values for the commercial and lab-made catalysts studied in this work

\begin{tabular}{ccccc}
\hline Catalyst & Commercial Pt/C & Lab-made Pt/C & $\mathbf{P t} /\left(\mathbf{S i}_{0.8} \mathbf{T i}_{\mathbf{0 . 2}}\right) \mathbf{C}$ & $\mathbf{P t} /\left(\mathbf{S i}_{\mathbf{0 . 9}} \mathbf{T i}_{\mathbf{0 . 1}}\right) \mathbf{C}$ \\
\hline $\mathbf{E C S A}\left(\mathbf{m}^{2} / \mathbf{g P t}\right)$ & 45.08 & 14.07 & 13.69 & 17.49 \\
\hline
\end{tabular}

Nevertheless, the lab-made Pt/C had an ECSA similar to the lab-made platinum catalysts supported on $\mathrm{SiC} / \mathrm{TiC}$, meaning that the synthesis method is of great importance. When comparing the catalyst obtained by the same synthesis method but with different catalyst support, the catalyst that shows the larger ECSA is $\mathrm{Pt} /\left(\mathrm{Si}_{0.9} \mathrm{Ti}_{0.1}\right) \mathrm{C}$. A value $24 \%$ higher than that 
for the catalyst supported on carbon. On the other hand, the catalysts with the lower ECSA is $\mathrm{Pt} /\left(\mathrm{Si}_{0.8} \mathrm{Ti}_{0.2}\right) \mathrm{C}$, which also showed the largest platinum crystallyte size.

Stability and $\mathrm{SO}_{2}$ oxidation efficiency were investigated with a chronoamperometry test in a $\mathrm{H}-$ cell for 14 hours. For all the experiments a potential of $1.0 \mathrm{~V}$ was applied. As electrode area was too small, $\mathrm{SO}_{2}$ consumption was so low that the $\mathrm{SO}_{2}$ consumption was too difficult to determine by means of iodometry if the anolyte was saturated with $\mathrm{SO}_{2}$ (the consumption was too low, that it is was difficult to observe differences between the initial and final $\mathrm{SO}_{2}$ concentration). For that reason, $\mathrm{SO}_{2}$ was bubbled for just 1 minute, to reach a low $\mathrm{SO}_{2}$ concentration, so a decrease in concentration could be easily observed at the beginning and at the end of the experiment. As saturation was not reached, a heterogeneous system in which initial $\mathrm{SO}_{2}$ concentrations were different for each case were obtained. For comparison, the obtained intensity was normalized in terms of initial $\mathrm{SO}_{2}$ concentration, so the results could be compared no matter the initial $\mathrm{SO}_{2}$ concentration. This normalized intensity vs time is shown in Figure 5.

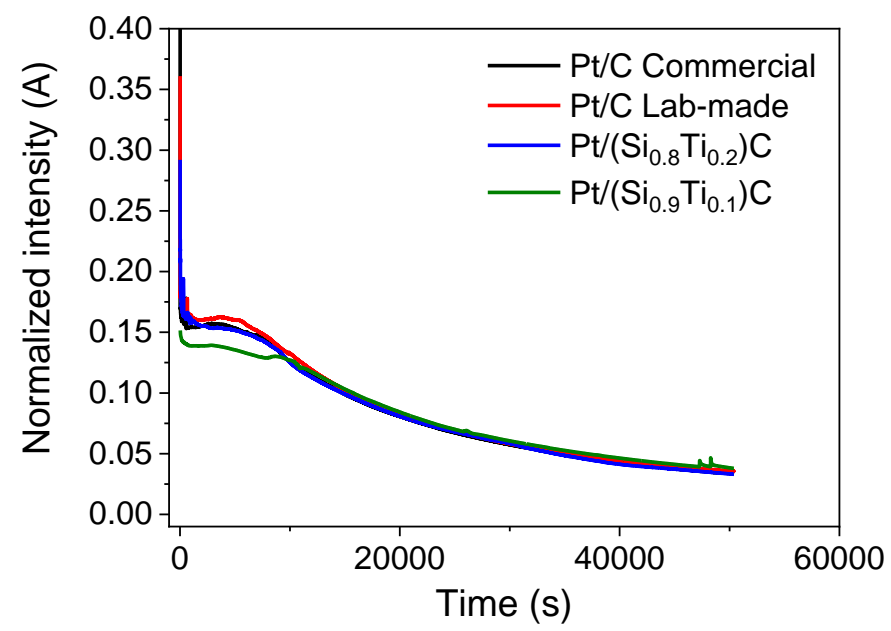

Figure 5. Chronoamperometry tests of the different employed catalysts. Conditions: $20^{\circ} \mathrm{C}, 1 \mathrm{M}$ $\mathrm{H}_{2} \mathrm{SO}_{4}, 1 \mathrm{~V}$ vs $\mathrm{RHE}$

Normalized chronoamperometry results show no noticeable difference among the studied catalysts, although in the case of $\mathrm{Pt} /\left(\mathrm{Si}_{0.9} 0 \mathrm{Ti}_{0.1}\right) \mathrm{C}$ there is a deviation in the firsts hours which is then corrected for the most part of the experiment. 
These results indicate that despite the catalyst particle size is different for the prepared and commercial catalysts, the behaviour for $\mathrm{SO}_{2}$ oxidation is similar. Meaning that, even though the catalysts supported on $\left(\mathrm{Si}_{\mathrm{x}} \mathrm{Ti}_{\mathrm{y}}\right) \mathrm{C}$ have a larger particle size, therefore a lower platinum utilization, they have the same capacity of oxidizing $\mathrm{SO}_{2}$ than the commercial Pt/C. This indicates that the catalysts had no limiting effect in this case and that a lower platinum loading could be used [19].

$\mathrm{SO}_{2}$ consumption by oxidation was estimated for each experiment by taking into consideration the desorbed $\mathrm{SO}_{2}$ during the duration of the experiment. To do so, a first experiment in which no current was applied between the electrodes was carried out and $\mathrm{SO}_{2}$ concentration was measured at the beginning and end of the experiment. This real consumption and the efficiency for $\mathrm{SO}_{2}$ oxidation is shown in Table 3.

Table 3. $\mathrm{SO}_{2}$ consumption

\begin{tabular}{|c|c|c|c|c|}
\hline Consumption & Commercial Pt/C & Lab-made Pt/C & $\mathbf{P t} /\left(\mathbf{S i}_{0.8} \mathbf{T i}_{0.2}\right) \mathrm{C}$ & $\mathbf{P t} /\left(\mathbf{S i}_{0.9} \mathbf{T i}_{0.1}\right) \mathrm{C}$ \\
\hline $\begin{array}{c}\text { Electrolysis } \\
\text { consumption } \\
\mathrm{Y}_{\text {elect }}(\mathbf{m m o l})\end{array}$ & $15.90 \pm 2.67$ & $11.96 \pm 3.96$ & $24.40 \pm 5.21$ & $12.92 \pm 2.88$ \\
\hline $\begin{array}{c}\text { Theoretical } \\
\text { consumption } \\
\mathbf{Y}_{\text {theor }}(\mathbf{m m o l})\end{array}$ & $19.92 \pm 00$ & $21.52 \pm 00$ & $24.33 \pm 00$ & $19.07 \pm 00$ \\
\hline Efficiency [\%] & $79.82 \pm 13.40$ & $55.58 \pm 18.40$ & $100.28 \pm 21.41$ & $67.75 \pm 15.10$ \\
\hline
\end{tabular}

The efficiency of $\mathrm{SO}_{2}$ electro-oxidation for the commercial $\mathrm{Pt} / \mathrm{C}$ catalysts is observed to be higher than for the lab-made $\mathrm{Pt} / \mathrm{C}$ and for the $\mathrm{Pt} /\left(\mathrm{Si}_{0.9} \mathrm{Ti}_{0.1}\right) \mathrm{C}$. On the other hand, the efficiency for $\mathrm{Pt} /\left(\mathrm{Si}_{0.8} \mathrm{Ti}_{0.2}\right) \mathrm{C}$ is around $100 \%$ which can be caused due to measurement method errors because of its low accuracy. Nevertheless, these results indicate that the $\mathrm{SO}_{2}$ depolarized electrolysis has a very good efficiency. 
Although table 2 shows that ECSA values are higher for the commercial catalyst than for the

lab-made catalyst, the efficiency and consumption for the $\mathrm{SO}_{2}$ depolarized electrolysis does not

seem dependent on this value. The catalytic activity does not only rely on the ECSA value but

also on the predominant exposed plane [49] which may lead a catalyst to have better efficiency

with lower ECSA values. Furthermore, as reported by other authors, the $\mathrm{SO}_{2}$ depolarized

electrolysis is a fast reaction and as consumption values indicate, the ECSA and the amount of

platinum were not a limitation $[16,48]$.

In order to investigate if the reduction in obtained intensity during the chronoamperometry is caused by catalyst degradation or by $\mathrm{SO}_{2}$ concentration reduction, which leads to mass transfer limitations, 20 linear voltammetries were carried out before and after the chronoamperometry tests. Figure 6 and Table 4 show these results for the different studied catalysts.
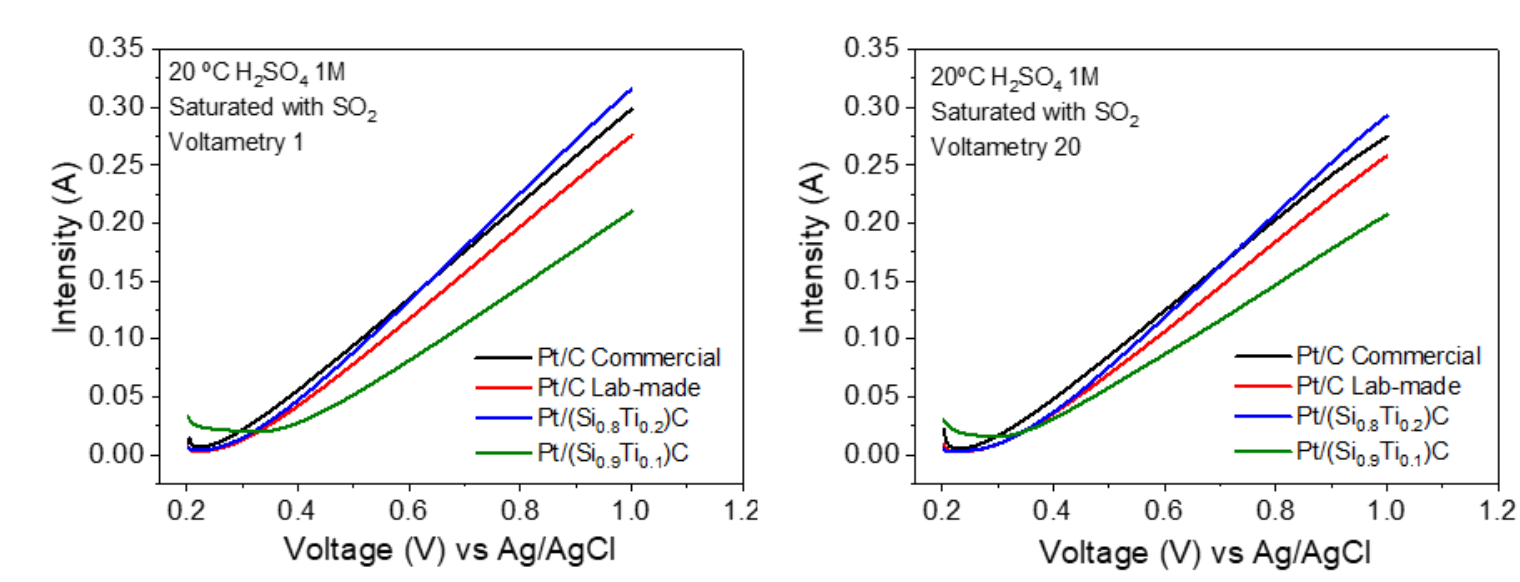

Figure 6. Lineal Voltammetries for the different catalysts. Conditions: $20^{\circ} \mathrm{C}, 1 \mathrm{M} \mathrm{H}_{2} \mathrm{SO}_{4}$ (saturated with $\mathrm{N}_{2}$ ). a) $1^{\text {st }}$ lineal Voltammetry, b) $20^{\text {th }}$ Lineal Voltammetry

As observed in Figure 6 and Table 4, the obtained intensities are very similar before and after the chronoamperometry tests. Meaning that the reduction on intensity during these long experiments is mostly caused by $\mathrm{SO}_{2}$ consumption and not to catalyst degradation. Taking these results into consideration, if a small amount of $\mathrm{SO}_{2}$ is bubbled, the obtained intensity could be held for longer time. Furthermore, it should be noted the good stability of the catalyst $\mathrm{Pt} /\left(\mathrm{Si}_{0.9} \mathrm{Ti}_{0.1}\right) \mathrm{C}$, which reaches higher intensity after the chronoamperometry test than before the 
test. Being this intensity even higher than the obtained for the commercial catalyst after the chronoamperometry at potentials higher than $0.7 \mathrm{~V}$ (Figure 6).

Table 4. Intensity comparison for the different catalysts at $1 \mathrm{~V}$ vs RHE

\begin{tabular}{|c|c|c|c|c|}
\hline & \multicolumn{4}{|c|}{ Intensity (A) } \\
\hline & \multicolumn{2}{|c|}{ Before Chronoamperometry } & \multicolumn{2}{|c|}{ After Chronoamperometry } \\
\hline & Voltametry 1 & Voltametry 20 & Voltametry 1 & Voltametry 20 \\
\hline Commercial Pt/C & 0.31 & 0.24 & 0.30 & 0.27 \\
\hline Lab-made Pt/C & 0.30 & 0.28 & 0.28 & 0.26 \\
\hline $\mathbf{P t} /\left(\mathbf{S i}_{0.8} \mathbf{T i}_{0.2}\right) \mathrm{C}$ & 0.22 & 0.22 & 0.32 & 0.29 \\
\hline $\mathbf{P t} /\left(\mathbf{S i}_{0.9} \mathbf{T i}_{0.1}\right) \mathrm{C}$ & 0.24 & 0.23 & 0.21 & 0.23 \\
\hline
\end{tabular}

\section{Conclusions}

From this work, the following conclusions can be drawn:

- $\mathrm{SiCTiC}$ based materials are promising catalyst supports to be used for the $\mathrm{SO}_{2}$ electrochemical oxidation in the Westinghouse cycle as they showed high catalyst activity and stability in sulphuric acid electrolyte.

- Although carbonaceous (Vulcan XC72) and non-carbonaceous supports (SiCTiC) were suitable to deposit successfully $40 \%$ wt of Pt on them, particle size distribution obtained is rather different. The catalysts supported on Vulcan carbon showed better distribution with lower average Pt particle size.

- The catalyst synthesis method has a great importance on the ECSA values. Among the catalyst manufactured in this work, the $\mathrm{Pt} /\left(\mathrm{Si}_{0.9} \mathrm{Ti}_{0.1}\right) \mathrm{C}$ obtained the highest ECSA 
- $\mathrm{Pt} /\left(\mathrm{Si}_{0.8} \mathrm{Ti}_{0.2}\right) \mathrm{C}$ catalyst reached the highest activity towards the $\mathrm{SO}_{2}$ electro-oxidation. $\mathrm{Pt} /\left(\mathrm{Si}_{0.9} \mathrm{Ti}_{0.1}\right) \mathrm{C}$ catalyst achieved the highest stability.

\section{Acknowledgements}

This research was funded by the Junta de Comunidades de Castilla-La Mancha and the FEDER EU Program, Project ASEPHAM. Grant number "SBPLY/17/180501/000330".Therefore, these Institutions are gratefully acknowledged.

\section{References}

1. Kriek, R.J.; Rossmeisl, J.; Siahrostami, S.; Björketun, M.E. H2production through electro-oxidation of SO2: Identifying the fundamental limitations. Phys. Chem. Chem. Phys. 2014, 16, 9572-9579, doi:10.1039/c4cp00705k.

2. Corgnale, C.; Summers, W.A. Solar hydrogen production by the Hybrid Sulfur process. Int. J. Hydrogen Energy 2011, 36, 11604-11619, doi:10.1016/j.ijhydene.2011.05.173.

3. Clarke, D.P.; Al-Abdeli, Y.M.; Kothapalli, G. The impact of renewable energy intermittency on the operational characteristics of a stand-alone hydrogen generation system with on-site water production. Int. J. Hydrogen Energy 2013, 38, 12253-12265, doi:10.1016/j.ijhydene.2013.07.031.

4. $\quad$ Ould Amrouche, S.; Rekioua, D.; Rekioua, T.; Bacha, S. Overview of energy storage in renewable energy systems. Int. J. Hydrogen Energy 2016, 41, 20914-20927, doi:10.1016/j.ijhydene.2016.06.243.

5. Winter, C.J.; Nitsch, J. Hydrogen as an Energy Carrier: Technologies, Systems, Economy; Springer Berlin Heidelberg, 2012; ISBN 9783642615610.

6. Gahleitner, G. Hydrogen from renewable electricity: An international review of power- 
to-gas pilot plants for stationary applications. Int. J. Hydrogen Energy 2013, 38, 20392061, doi:10.1016/j.ijhydene.2012.12.010.

7. $\quad$ Bhosale, R.R.; Kumar, A.; Broeke, L.J.P. Van Den; Gharbia, S.; Dardor, D.; Jilani, M.; Folady, J.; Al-fakih, M.S. Solar hydrogen production via thermochemical iron oxide-iron sulfate water splitting cycle. Int. J. Hydrogen Energy 2014, 40, 1639-1650, doi:10.1016/j.ijhydene.2014.11.118.

8. Xinxin, W.; Kaoru, O. Thermochemical Water Splitting for Hydrogen Production Utilizing Nuclear Heat from an HTGR *. Tsinghua Sci. Technol. 2005, 10, 270-276.

9. Bilgen, E. Solar hydrogen production by hybrid thermochemical processes. Sol. Energy 1988, 41, 199-206, doi:DOI. 10.1016/0038-092X(88)90137-5.

10. Weidner, J.W.; Sivasubramanian, P.; Holland, C.E.; Freire, F.J. Electrochemical Generation of Hydrogen via Gas Phase Oxidation of Sulfur Dioxide and Hydrogen Bromide Hydrogen using Thermal and / or Electrical Energy. 2005.

11. Li, X.; Yu, J.; Low, J.; Fang, Y.; Xiao, J.; Chen, X. Engineering heterogeneous semiconductors for solar water splitting. J. Mater. Chem. A Mater. energy Sustain. 2014, 00,1-50, doi:10.1039/C4TA04461D.

12. O’Brien, J.A.; Hinkley, J.T.; Donne, S.W.; Lindquist, S.E. The electrochemical oxidation of aqueous sulfur dioxide: A critical review of work with respect to the hybrid sulfur cycle. Electrochim. Acta 2010, 55, 573-591, doi:10.1016/j.electacta.2009.09.067.

13. Thomey, D.; De Oliveira, L.; Säck, J.P.; Roeb, M.; Sattler, C. Development and test of a solar reactor for decomposition of sulphuric acid in thermochemical hydrogen production. Int. J. Hydrogen Energy 2012, 37, 16615-16622, doi:10.1016/j.ijhydene.2012.02.136.

14. Gorensek, M.B. Hybrid sulfur cycle flowsheets for hydrogen production using hightemperature gas-cooled reactors. Int. J. Hydrogen Energy 2011, 36, 12725-12741, 
doi:10.1016/j.ijhydene.2011.07.033.

15. M. B. Gorensek, W. A. Summers, C. O. Bolthrunis, E. J. Lahoda, D. T. Allen, R.G. Hybrid Sulfur Process Reference Design and Cost Analysis - Final Report. SRNLL1200-2008-00002 2009.

16. Allen, J.A.; Rowe, G.; Hinkley, J.T.; Donne, S.W. Electrochemical aspects of the Hybrid Sulfur Cycle for large scale hydrogen production. Int. J. Hydrogen Energy 2014, 39, 11376-11389, doi:10.1016/j.ijhydene.2014.05.112.

17. Chen, X.; Qian, G.; Molleo, M.A.; Benicewicz, B.C.; Ploehn, H.J. High temperature creep behavior of phosphoric acid-polybenzimidazole gel membranes. J. Polym. Sci. Part B Polym. Phys. 2015, 53, 1527-1538, doi:10.1002/polb.23791.

18. Kaur, H.; Wang, M.; Gorensek, M.B.; Chen, C.C. Thermodynamic modeling of the hybrid sulfur (HyS) cycle for hydrogen production. Fluid Phase Equilib. 2018, 460, 175-188, doi:10.1016/j.fluid.2017.12.025.

19. Jayakumar, J.V.; Gulledge, A.; Staser, J.A.; Kim, C.-H.; Benicewicz, B.C.; Weidner, J.W. Polybenzimidazole Membranes for Hydrogen and Sulfuric Acid Production in the Hybrid Sulfur Electrolyzer. ECS Electrochem. Lett. 2012, 1, F44-F48.

20. Steimke, J.L.; Steeper, T.J.; Cólon-Mercado, H.R.; Gorensek, M.B. Development and testing of a PEM SO2-depolarized electrolyzer and an operating method that prevents sulfur accumulation. Int. J. Hydrogen Energy 2015, 40, 13281-13294, doi:10.1016/j.ijhydene.2015.08.041.

21. Krüger, A.J.; Krieg, H.M.; Van Der Merwe, J.; Bessarabov, D. Evaluation of MEA manufacturing parameters using EIS for SO2electrolysis. Int. J. Hydrogen Energy 2014, 39, 18173-18181, doi:10.1016/j.ijhydene.2014.09.012.

22. Díaz-Abad, S.; Millán, M.; Rodrigo, M.A.; Lobato, J. Review of Anodic Catalysts for SO2 Depolarized Electrolysis for "Green Hydrogen” Production. Catalysts 2019, 9, 63, 
doi:10.3390/catal9010063.

23. Sharma, S.; Pollet, B.G. Support materials for PEMFC and DMFC electrocatalysts - A review. J. Power Sources 2012, 208, 96-119, doi:10.1016/j.jpowsour.2012.02.011.

24. Chen, Z.; Higgins, D.; Yu, A.; Zhang, L.; Zhang, J. A review on non-precious metal electrocatalysts for PEM fuel cells. Energy Environ. Sci. 2011, 4, 3167-3192, doi:10.1039/c0ee00558d.

25. Shao, Y.; Liu, J.; Wang, Y.; Lin, Y. Novel catalyst support materials for PEM fuel cells: Current status and future prospects. J. Mater. Chem. 2009, 19, 46-59, doi:10.1039/b808370c.

26. Wang, Y.-J.; Wilkinson, D.P.; Zhang, J. Noncarbon Support Materials for Polymer Electrolyte Membrane Fuel Cell Electrocatalysts. Chem. Rev. 2011, 111, 7625-7651, doi:10.1021/cr100060r.

27. Lobato, J.; Zamora, H.; Plaza, J.; Cañizares, P.; Rodrigo, M.A. Enhancement of high temperature PEMFC stability using catalysts based on Pt supported on SiC based materials. Appl. Catal. B Environ. 2016, 198, 516-524, doi:10.1016/j.apcatb.2016.06.011.

28. Chen, G.; Xia, D.; Nie, Z.; Wang, Z.; Wang, L.; Zhang, L.; Zhang, J. Facile synthesis of Co-Pt hollow sphere electrocatalyst. Chem. Mater. 2007, 19, 1840-1844, doi:10.1021/cm062336z.

29. Sasaki, K.; Mo, Y.; Wang, J.X.; Balasubramanian, M.; Uribe, F.; McBreen, J.; Adzic, R.R. Pt submonolayers on metal nanoparticles - Novel electrocatalysts for $\mathrm{H} 2$ oxidation and O 2 reduction. Electrochim. Acta 2003, 48, 3841-3849, doi:10.1016/S00134686(03)00518-8.

30. Stamenković, V.; Schmidt, T.J.; Ross, P.N.; Marković, N.M. Surface composition effects in electrocatalysis: Kinetics of oxygen reduction on well-defined Pt3Ni and 
Pt3Co alloy surfaces. J. Phys. Chem. B 2002, 106, 11970-11979,

doi:10.1021/jp021182h.

31. Kim, J.Y.; Oh, T.K.; Shin, Y.; Bonnett, J.; Weil, K.S. A novel non-platinum group electrocatalyst for PEM fuel cell application. Int. J. Hydrogen Energy 2011, 36, 45574564, doi:10.1016/j.ijhydene.2010.05.016.

32. Evans, S.A.G.; Terry, J.G.; Plank, N.O.V.; Walton, A.J.; Keane, L.M.; Campbell, C.J.; Ghazal, P.; Beattie, J.S.; Su, T.J.; Crain, J.; et al. Electrodeposition of platinum metal on TiN thin films. Electrochem. commun. 2005, 7, 125-129, doi:10.1016/j.elecom.2004.11.014.

33. Basu, B.; Raju, G.B.; Suri, A.K. Processing and properties of monolithic TiB2 based materials. Int. Mater. Rev. 2006, 51, 352-374, doi:10.1179/174328006X102529.

34. Venkateswara Rao, C.; Singh, S.K.; Viswanathan, B. Electrochemical performance of nano-SiC prepared in thermal plasma. Indian J. Chem. - Sect. A Inorganic, Phys. Theor. Anal. Chem. 2008, 47, 1619-1625.

35. Mazza, F.; Trassatti, S. Tungsten, Titanium, and Tantalum Carbides and Titanium Nitrides as Electrodes in Redox Systems. P-N JUNCTION Photovolt. Eff. 1963, 110, 847-849.

36. Zamora, H.; Plaza, J.; Velhac, P.; Cañizares, P.; Rodrigo, M.A.; Lobato, J. SiCTiC as catalyst support for HT-PEMFCs. Influence of Ti content. Appl. Catal. B Environ. 2017, 207, 244-254, doi:10.1016/j.apcatb.2017.02.019.

37. Lobato, J.; Zamora, H.; Cañizares, P.; Plaza, J.; Rodrigo, M.A. Microporous layer based on $\mathrm{SiC}$ for high temperature proton exchange membrane fuel cells. J. Power Sources 2015, 288, 288-295, doi:10.1016/j.jpowsour.2015.04.102.

38. Millán, M.; Zamora, H.; Rodrigo, M.A.; Lobato, J. Enhancement of Electrode Stability Using Platinum-Cobalt Nanocrystals on a Novel Composite SiCTiC Support. ACS Appl. 
Mater. Interfaces 2017, 9, 5927-5936, doi:10.1021/acsami.6b13071.

39. Lobato, J.; Cañizares, P.; Rodrigo, M.A.; Úbeda, D.; Pinar, F.J.; Linares, J.J.

Optimisation of the Microporous Layer for a Polybenzimidazole-Based High

Temperature PEMFC - Effect of Carbon Content. Fuel Cells 2010, 10, 770-777, doi:10.1002/fuce.200900175.

40. Grubbs, F.E. Procedures for Detecting Outlying Observations in Samples. Technometrics 1969, 11, 1-21, doi:10.1080/00401706.1969.10490657.

41. Zamora, H.; Plaza, J.; Velhac, P.; Ca, P.; Rodrigo, M.A.; Lobato, J. SiCTiC as catalyst support for HT-PEMFCs . Influence of Ti content. Appl. Catal. B Environ. 2017, 207, 244-254, doi:10.1016/j.apcatb.2017.02.019.

42. Jiménez, V.; Nieto-Márquez, A.; Díaz, J.A.; Romero, R.; Sánchez, P.; Valverde, J.L.; Romero, A. Pilot Plant Scale Study of the Influence of the Operating Conditions in the Production of Carbon Nanofibers. Ind. Eng. Chem. Res. 2009, 48, 8407-8417, doi:10.1021/ie9005386.

43. Lobato, J.; Zamora, H.; Plaza, J.; Rodrigo, M.A. Composite Titanium Silicon Carbide as a Promising Catalyst Support for High-Temperature Proton-Exchange Membrane Fuel Cell Electrodes. ChemCatChem 2016, 8, 848-854, doi:10.1002/cctc.201501152.

44. Lobato, J.; Cañizares, P.; Rodrigo, M.A.; Linares, J.J. Study of different bimetallic anodic catalysts supported on carbon for a high temperature polybenzimidazole-based direct ethanol fuel cell. Appl. Catal. B Environ. 2009, 91, 269-274, doi:10.1016/j.apcatb.2009.05.035.

45. Dhiman, R.; Stamatin, S.N.; Andersen, S.M.; Morgen, P.; Skou, E.M. Oxygen reduction and methanol oxidation behaviour of $\mathrm{SiC}$ based $\mathrm{Pt}$ nanocatalysts for proton exchange membrane fuel cells. J. Mater. Chem. A 2013, 1, 15509-15516, doi:10.1039/c3ta12744c.

46. Carmo, M.; dos Santos, A.R.; Poco, J.G.R.; Linardi, M. Physical and electrochemical 
evaluation of commercial carbon black as electrocatalysts supports for DMFC applications. J. Power Sources 2007, 173, 860-866, doi:10.1016/j.jpowsour.2007.08.032.

47. Wang, X.; Li, W.; Chen, Z.; Waje, M.; Yan, Y. Durability investigation of carbon nanotube as catalyst support for proton exchange membrane fuel cell. J. Power Sources 2006, 158, 154-159, doi:10.1016/j.jpowsour.2005.09.039.

48. Lee, S.K.; Kim, C.H.; Cho, W.C.; Kang, K.S.; Park, C.S.; Bae, K.K. The effect of Pt loading amount on SO2oxidation reaction in an SO2-depolarized electrolyzer used in the hybrid sulfur (HyS) process. Int. J. Hydrogen Energy 2009, 34, 4701-4707, doi:10.1016/j.ijhydene.2009.04.002.

49. Antoniassi, R.M.; Otubo, L.; Vaz, J.M.; Neto, A.O.; Spinacé, E. V Synthesis of Pt nanoparticles with preferential $\left(\begin{array}{lll}1 & 0 & 0\end{array}\right)$ orientation directly on the carbon support for Direct Ethanol Fuel Cell. 2016, 342, 67-74, doi:10.1016/j.jcat.2016.07.022. 